\title{
Substance P-induced Augmentation of Cutaneous Vascular Permeability and Granulocyte Infiltration in Mice Is Mast Cell Dependent
}

\author{
Hirohisa Yano, * Barry K. Wershil, ${ }^{\star \star}$ Naoki Arizono," and Stephen J. Galli* \\ *Departments of Pathology, Beth Israel Hospital and Harvard Medical School, Boston, Massachusetts 02215; The Charles A. Dana \\ Research Institute, Beth Israel Hospital, Boston, Massachusetts 02215; ${ }^{\ddagger}$ The Combined Pediatric Gastroenterology \\ and Nutrition Program, Harvard Medical School, Boston, Massachusetts 02215
}

\begin{abstract}
The undecapeptide substance $P$ is thought to mediate both vasodilatation and augmented vascular permeability when released from sensory nerve endings in the skin. Substance $P$ also induces mast cell degranulation in vitro or in vivo. However, the extent to which substance $P$-induced changes in vascular permeability are mast cell-dependent is unclear. We investigated this issue by injecting substance $P$ and certain related peptides (substance $P_{1-4}$, substance $P_{4-11}$ ) into the skin of genetically mast cell-deficient $\mathrm{WBB} \mathrm{F}_{1}-W / W^{v}$ or $\mathrm{WCB6F}_{1}$ $S l / S l^{d}$ mice, the congenic normal $(+/+)$ mice, and $W / W^{v}$ mice which had undergone selective local repair of their mast cell deficiency by intradermal injection of IL-3-dependent mast cells generated in vitro from the bone marrow cells of the congenic $+/+$ mice. Substance $P$ induced significant augmentation of vascular permeability and significant cutaneous swelling when injected into normal mice at doses as low as 2 pmol i.d. Substance $P$ also induced granulocyte infiltration, although the infiltrates were modest and were seen at doses of peptide from 5 to more than 20-fold higher than those required for induction of tissue swelling. The effects of substance $P$ on tissue swelling, vascular permeability, and granulocyte infiltration were virtually entirely mast cell dependent. By contrast, substance $P_{1-4}$ was inactive in our assays at $25 \mathrm{nmol} / \mathrm{site}$, and substance $\mathbf{P}_{4-11}$ induced modest augmentation of vascular permeability, which was at least in part mast cell independent.
\end{abstract}

\section{Introduction}

The extent to which mast cells participate in neuropeptide-dependent vascular changes is the subject of considerable current interest and some controversy. Several findings suggest that mast cells may importantly contribute to such processes. Kiernan demonstrated that antidromic electrical stimulation

Portions of this work were presented at the Annual Meeting of the Federation of American Societies for Experimental Biology, 21 March 1989, and published in abstract form in 1989 [FASEB (Fed. Am. Soc. Exp. Biol.) J. 3:A789.].

Address reprint requests to Dr. Galli, Department of Pathology Beth Israel Hospital, 330 Brookline Avenue, Boston, MA 02215. Dr. Arizono's present address is the Department of Medical Zoology, Kyoto Prefectural University of Medicine, Kyoto 602, Japan.

Received for publication 16 March 1989 and in revised form 15 May 1989.

J. Clin. Invest.

(c) The American Society for Clinical Investigation, Inc. $0021-9738 / 89 / 10 / 1276 / 11 \$ 2.00$

Volume 84, October 1989, 1276-1286
(ES) ${ }^{1}$ of sensory nerves induces cutaneous vasodilation and augmented vascular permeability, and also results in degranulation of cutaneous mast cells $(1,2)$. Several different neuropeptides which can induce alterations in vascular tone and/or permeability when injected in vivo can also stimulate degranulation of a variety of human and rodent mast cell populations in vitro or in vivo (reviewed in 3-16). Cutaneous mast cells are particularly sensitive to stimulation by substance $P(4,5-8$, $10-12,15,16)$, which can induce a wheal and flare response when injected into the skin in doses as low as 10 pmol (4-8, 11). Some neuropeptide-induced vascular changes, e.g., the flare observed immediately after injection of substance $P$, are markedly attenuated by administration of antihistamines (4, 8-11), suggesting that such effects may be mediated by neuropeptide-dependent mast cell degranulation. Finally, morphological studies have documented a very close anatomical association between mast cells and nonmyelinated nerves $(17,18)$, which in some studies have been shown to contain substance $P$ and/or other neuropeptides $(19,20)$.

Taken together, such evidence implicates mast cells as potentially important intermediaries between neuropeptide release and local alterations in vascular tone or permeability and other manifestations of inflammation. However, additional observations indicate that certain manifestations of neurogenic inflammation may occur independently of the mast cell. Investigation of the effects of $\mathrm{H}_{1}$ antihistamines on the expression of substance P-induced vascular changes in human skin indicate that while the flare response is largely histamine-mediated, the more prolonged wheal component of the reaction occurs through a combination of histamine-dependent and histamine-independent mechanisms (reviewed in 8, 11). And while some studies indicate that neurogenically stimulated augmentation of vascular permeability can be blocked partially by $H_{1}$ and $H_{2}$ receptor antagonists or by depletion of cutaneous mast cells $(21,22)$, other studies have not demonstrated a protective effect of antihistamines in similar systems (23-25).

Kowalski and Kaliner directly investigated the participation of mast cells in the cutaneous vascular changes induced by ES and demonstrated that while prolonged ES did cause degranulation of cutaneous mast cells, this response was detectable histologically only after significant augmentation of vascular permeability had already occurred (13). They also showed that disodium cromoglycate (DSCG), an inhibitor of mast cell degranulation, was not able to interfere with the augmentation in cutaneous vascular permeability induced by

1. Abbreviations used in this paper: ES, electrical stimulation; DSCG, disodium cromoglycate; HMEM, Hanks' minimal essential medium; PIPES, piperazine- $N, N^{\prime}$-bis [2-ethane sulfonic acid]; ${ }^{125} \mathrm{I}-\mathrm{GPF},{ }^{125} \mathrm{I}-$ guinea pig fibrinogen; PPP, platelet-poor plasma. 
ES, and demonstrated that genetically mast cell-deficient $\mathrm{WBB} \mathrm{F}_{1}-W / W^{v}$ mice and the congenic normal mice (WBB6F ${ }_{1}-+/+$ mice) exhibited no differences in the magnitude of vascular permeability responses to either ES or intravenous administration of substance $P{ }^{2}$ The latter observation is in accord with studies showing that substance $P$ injected intraarterially or intravenously has a rapid vasodilatory effect on human skin that is not blocked by an antihistamine (promethazine), atropine, or adrenergic blocking agents (26). In aggregate, this evidence suggests that at least certain aspects of neurogenic or substance P-induced alterations in vascular function, and in particular augmented vascular permeability, may occur by mast cell-independent mechanisms.

To investigate directly the role of mast cells in substance P-induced alterations of vascular permeability, we injected substance $P$ directly into the skin of genetically mast cell-deficient $\mathrm{WBB} \mathrm{F}_{1}-W / W^{\nu}$ or $\mathrm{WCB}^{2} \mathrm{~F}_{1}-S l / S l^{d}$ mice, the congenic normal $(+/+)$ mice, and $W / W^{\nu}$ mice that had undergone selective local repair of their cutaneous mast cell deficiency by adoptive intracutaneous transfer of growth factor-dependent mast cells generated in vitro from bone marrow cells derived from the congenic $+/+$ mice. In accord with the results of Matsuda et al. (27), who demonstrated that substance P-induced granulocyte infiltration into subcutaneous air pouches in the mouse was largely mast cell dependent, we found that virtually all of the leukocyte infiltration following i.d. injection of substance $P$ was dependent on mast cells. However, we found that substance $P$ induced significant augmentation of cutaneous vascular permeability and tissue swelling when injected intradermally in doses as low as 2 pmol, amounts that induced no significant infiltration of leukocytes. Virtually all of the tissue swelling induced by intradermal injection of substance $\mathbf{P}$ was mast cell dependent.

\section{Methods}

Mice. Mast cell-deficient mice and the normal $(+/+)$ littermates $\left(\left(\mathrm{WB} / \mathrm{ReJ}-W /+\times \mathrm{C} 57 \mathrm{BL} / 6 \mathrm{~J}-W^{\nu} /+\right) \mathrm{F}_{1}-\left(W / W^{v},+/+\right)\right.$, designated here $\left.\mathrm{WBB} \mathrm{F}_{1}-W / W^{v},+/+\right)$, and (WC/ReJ-Sl/ $+\times \mathrm{C} 57 \mathrm{BL} / 6 \mathrm{~J}-\mathrm{Sl}^{d} /$ $\left.+) \mathrm{F}_{1}-S l / S l^{d},+/+\right)$, designated here $\mathrm{WCB} \mathrm{F}_{1}-\left(S l / S l^{d},+/+\right)$ were purchased from the Jackson Laboratory (Bar Harbor, ME). The skin of adult $\mathrm{WBB} \mathrm{F}_{1}-W / W^{v}$ or $\mathrm{WCB} \mathrm{F}_{1}-S l / S l^{d}$ mice contains $<1.0 \%$ the number of mast cells present in the skin of the congenic normal $(+/+)$ mice (28-30). All mice were males and were used at 4-7 mo of age unless stated otherwise.

Elicitation and analysis of tissue swelling induced by substance $P$. Native substance $P$ (substance $P_{1-11}$ ), substance $P_{1-4}$, and substance $\mathbf{P}_{4-11}$ purchased from Peninsula Laboratories, Inc. (Belmont, $\left.C A\right)$ were either solubilized in vehicle immediately before injection or were made up as stock solutions, frozen at $-70^{\circ} \mathrm{C}$, then thawed within 2 wk, diluted, and used immediately. Peptides were solubilized either in Hanks' minimal essential medium (HMEM; Gibco Laboratories, Grand Island, NY) containing $0.47 \mathrm{~g} /$ liter piperazine- $N, N^{\prime}$-bis [2-ethane sulfonic acid] (PIPES buffer) instead of $\mathrm{NaHCO}_{3}$ (HMEM-PIPES), in Hanks' balanced salt solution lacking $\mathrm{Ca}^{2+}$ and $\mathrm{Mg}^{2+}\left(\mathrm{Ca}^{2+} / \mathrm{Mg}^{2+}-\right.$ free HBSS; Gibco Laboratories), or in $\mathrm{Ca}^{2+} / \mathrm{Mg}^{2+}$-free HBSS to which was added $1.3 \mathrm{mM} \mathrm{CaCl}_{2}\left(\mathrm{HBSS}-\mathrm{Ca}^{2+}\right)$. Unless stated otherwise, mice received an injection of peptide ( $20 \mu \mathrm{l} / \mathrm{site}$, via a 30 gauge needle) intradermally into the left ear and an injection of the vehicle of the peptide $(20 \mu \mathrm{l} /$ site i.d.) into the right (control) ear. All injections and measurements of ear thickness were performed with the mice under light ether anesthesia.

The responses in both experimental and control ears were evalu-

2. Kaliner, M. L., personal communication. ated by several methods, all of which have been described in detail. Ear thickness was measured with a micrometer before and at various intervals after injection; swelling was expressed as the increment $(\Delta)$ of thickness (postinjection value - baseline value) in units of $10^{-4}$ inch (31).

Assessment of substance P-induced ${ }^{125} I$-fibrin deposition. In some experiments, an additional sensitive assay of altered vascular permeability was used: extravasation of ${ }^{125}$ I-guinea pig fibrinogen ( ${ }^{125} \mathrm{I}$-GPF) and deposition of ${ }^{125} \mathrm{I}$-fibrin $(32,33)$. At 10 to $30 \mathrm{~min}$ before challenge with peptides, the mice were injected intravenously with ${ }^{125}$ I-GPF (usually, $\sim 5 \times 10^{6} \mathrm{cpm}$ ). The swelling responses in peptide-injected and control ears were measured with a micrometer as described above, then the mice were killed at $2 \mathrm{~h}$ after challenge. A mixture of anticoagulants and antifibrinolytic agents was injected intravenously to impede further clotting or fibrinolysis during specimen preparation: each mouse received $0.2 \mathrm{ml}$ of a mixture containing $80 \mathrm{U}$ heparin, $20 \mu \mathrm{g}$ D-phenylalanyl-L-prolyl-L-arginine chloromethyl ketone, $2 \mu \mathrm{g}$ e-aminocaproic acid, and $56 \mathrm{U}$ trasylol, all in $0.15 \mathrm{M} \mathrm{NaCl}$ (32-34). Immediately thereafter, the mice were lightly anesthetized with ether and a sample of retroorbital blood was obtained. These samples, which exhibited no clotting during an observation period of $3 \mathrm{~h}$, were centrifuged at $10,000 \mathrm{~g}$ at room temperature to prepare platelet-poor plasma (PPP) for radioactive counting. The mice were killed by cervical dislocation immediately after retroorbital blood had been obtained, and both ears were amputated and trimmed. A small full-thickness biopsy of each ear was fixed as described below for histologic studies. The rest of each ear was then promptly minced into fine fragments in $2 \mathrm{ml} 0.01$ M phosphate buffer ( $\mathrm{pH} 7.5$ ) containing a mixture of proteolytic inhibitors: heparin $(10 \mathrm{U} / \mathrm{ml})$, D-phenylalanyl-L-prolyl-L-arginine chloromethyl ketone $(5 \mathrm{mg} / \mathrm{ml})$. EDTA $(2 \mathrm{mg} / \mathrm{ml}), \epsilon$-aminocaproic acid $(0.1$ M), Trasylol (10 U/ml), $2 \mathrm{mM} \mathrm{PMSF,} 2 \mathrm{mM}$ iodoacetate, and $2 \mathrm{mM}$ $N$-ethylmaleimide (32-34).

The minced ears were then extracted in the buffer by keeping the tubes for $18 \mathrm{~h}$ at $4^{\circ} \mathrm{C}$. Each tube was centrifuged $(1,000 \mathrm{~g}$ for $20 \mathrm{~min}$ at $20^{\circ} \mathrm{C}$ ) and supernatant was decanted. The pellet containing the tissue fragments was resuspended vigorously in $2 \mathrm{ml}$ of the same buffer and was centrifuged again, as above. The supernatant was aspirated and pooled with the earlier extract for radioactive counting as the "aqueous extract." The pelleted tissue fragments then were suspended in $2 \mathrm{ml}$ freshly prepared $3 \mathrm{M}$ urea, extracted for $2 \mathrm{~h}$ at $37^{\circ} \mathrm{C}$, centrifuged $(1,000$ $g$ for $20 \mathrm{~min}$ at $20^{\circ} \mathrm{C}$ ), and the urea soluble supernatant and the urea insoluble pellet counted for radioactivity in a Tracor Analytic 1185 gamma counter. The ${ }^{125} \mathrm{I}-\mathrm{GPF}-$ derived species present in guinea pig (34) or mouse $(32,33)$ tissues consisted of a mixture of fibrinogen, fibrin, and fibrinogen-fibrin degradation products. Fibrinogen, fibrin monomers, and solubilized fibrin degradation products appeared in the aqueous extract; fibrin polymers not cross-linked by Factor XIII appeared in the "urea soluble" GPF extract; and cross-linked fibrin as well as some early degradation fragments of cross-linked fibrin appeared in the "urea insoluble" residue.

Assessment of substance P-induced mast cell degranulation and granulocyte infiltration. In all experiments, samples of peptide-injected and control (vehicle-injected) ears were obtained after sacrifice and processed for 1- $\mu \mathrm{m}$ Epon-embedded, Giemsa-stained sections $(35,36)$. The sections were examined by an observer not aware of the identity of the individual specimens. The number of dermal mast cells per square millimeter of dermis was determined (37) and the cells were classified (at $\times 1,000)$ as extensively degranulated $(>50 \%$ of the cytoplasmic granules exhibiting fusion, staining alterations, and extrusion from the cell), slightly to moderated degranulated $(10-50 \%$ of the granules exhibiting fusion or discharge), or normal $(37,38)$. We also quantitated the number of granulocytes present near the injection site, and expressed the results as granulocytes $/ \mathrm{mm}^{2}$ of dermis, as previously described (37). In Giemsa-stained 1- $\mu \mathrm{m}$ Epon-embedded sections, mouse neutrophils have a polylobed nucleus and small, poorly stained cytoplasmic granules, whereas the eosinophils have a bilobed or polylobed nucleus and larger, refractile, light green granules. In the leukocytic infiltrates analyzed in this report, $>90 \%$ of the cells were neutrophils. 
Mast cell reconstitution. $\mathrm{WBB} \mathrm{F}_{1}-W / W^{\nu}$ mice were repaired of their mast cell deficiency selectively and locally by the injection of growth factor-dependent cultured mast cells into one ear $(33,37,39$, 40). We reported that IL-3-dependent, bone marrow-derived,

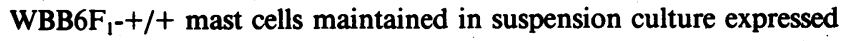
phenotypic similarities to mucosal mast cells, but that upon injection into the peritoneal cavity $(39,41,42)$ or skin $(33,37,39,40)$ of WBB6F $_{1}-W / W^{v}$ mice, these mast cell populations gradually (by $\sim 10$ wk) acquired multiple phenotypic characteristics of mature "serosal" or connective tissue-type mast cells present in normal mice. Moreover, injection of cultured mast cells into one ear of $W / W^{v}$ mice repairs only the mast cell deficiency of that ear; the mast cell deficiency of other cutaneous sites or other organs is not affected, nor is there any effect on the anemia of the $W / W^{v}$ recipients $(33,37,39,40)$. Briefly, bone marrow cells from $W_{B B} 6 F_{1}-+/+$ mice were grown in vitro for 3-5 wk in Con A-stimulated mouse spleen cell-conditioned medium until mast cells represented $>95 \%$ of the total cells according to staining by neutral red. Mast cells $\left(0.5 \times 10^{6}\right)$ in $20 \mu \mathrm{l}$ of HMEM were injected into the left ears and $20 \mu \mathrm{l}$ of medium alone into the right ears. The mice were challenged by injection of peptides into both ears $10 \mathrm{wk}$ or more after adoptive transfer of cultured mast cells. In all experiments, we confirmed histologically that local reconstitution of dermal mast cell populations had occurred and determined that the $W / W^{v}$ mice locally reconstituted with mast cells remained anemic.

Statistical analysis. The results of ear swelling assays and differences in mast cell or granulocyte counts were analyzed for statistical significance $(P<0.05)$ by Student's $t$ test (two-tailed), values for left and right ears in individual mice were compared by the paired Student's $t$ test (two tailed). The results of the ${ }^{125}$ I-fibrinogen influx and
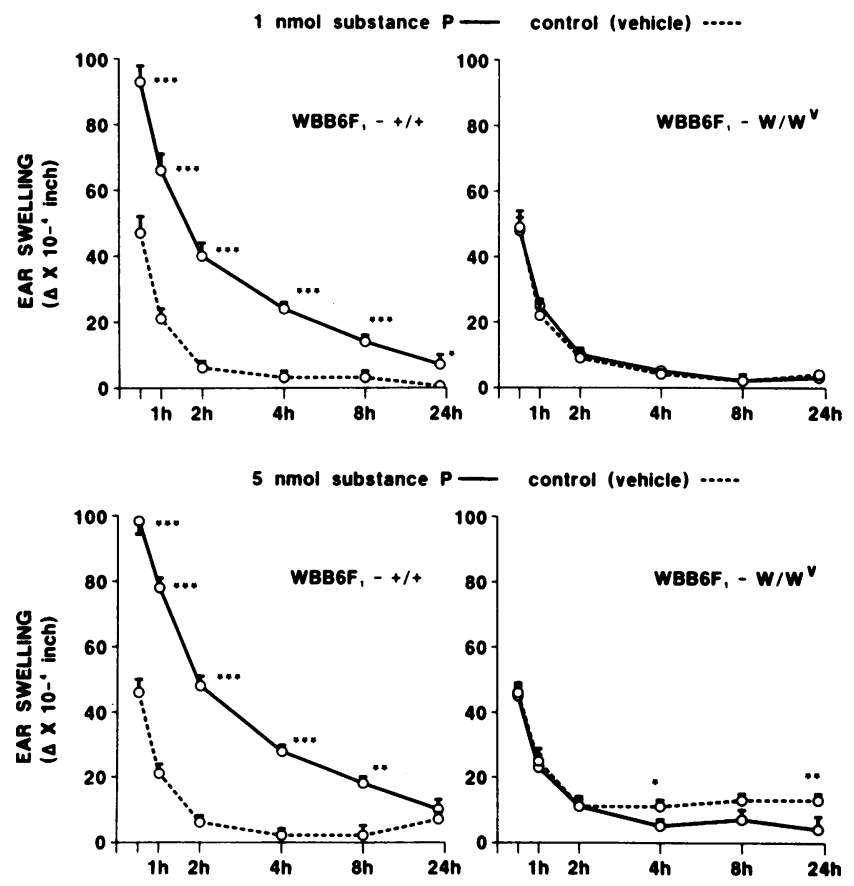

Figure 1. Ear swelling responses $(\Delta=$ postinjection thickness - preinjection baseline value) in genetically mast cell-deficient WBB6 $\mathrm{F}_{1}-W / W^{v}$ or congenic normal $(+/+)$ mice challenged in the left ear with 1 or $5 \mathrm{nmol}$ of substance $\mathrm{P}$ (in $20 \mu$ l HMEM-PIPES) and in the right (control) ear with HMEM-PIPES $(20 \mu \mathrm{l})$. Data represent mean $\pm \operatorname{SEM}$ ( $n=6$ to 22/point). Significant differences between values for $L$ (substance $P$-injected) and $R$ (vehicle-injected) ears are shown as: ${ }^{*} P<0.05,{ }^{* *} P<0.01,{ }^{* * *} P<0.001$. (The biological significance of the small differences between $\mathrm{L}$ and $\mathrm{R}$ ears in $W / W^{\nu}$ mice at late intervals after injection of $5 \mathrm{nmol}$ substance $P$ or vehicle is uncertain.)

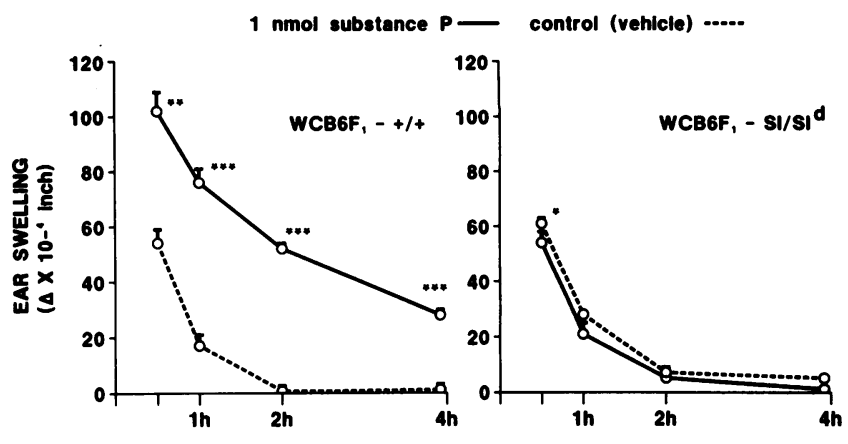

Figure 2. Ear swelling in genetically mast cell-deficient $\mathrm{WCB} \mathrm{F}_{1}-\mathrm{Sl} /$ $S l^{d}$ mice or congenic normal $(+/+)$ mice challenged in the left ear with $1 \mathrm{nmol}$ of substance $\mathrm{P}$ (in $20 \mu \mathrm{l}$ HMEM-PIPES) and in the right (control) ear with HMEM-PIPES $(20 \mu \mathrm{l})$. Data represent $\mathrm{m} \pm \mathrm{SEM}(n$ $=6 /$ point). Significant differences between values for $L$ and $R$ ears are shown as: ${ }^{*} P<0.05,{ }^{* *} P<0.01,{ }^{* * *} P \leq 0.001$.

${ }^{125}$ I-fibrin deposition assays were analyzed by the Mann-Whitney $U$ test (two tailed).

All results are expressed as mean \pm SEM.

\section{Results}

Substance $P$ induces tissue swelling in normal $(+/+)$ but not genetically mast cell-deficient mice. In the first series of experiments, substance $P$ was injected intradermally (1 or $5 \mathrm{nmol} /$ site) into the left ears of genetically mast cell-deficient $\mathrm{WBB} \mathrm{F}_{1}-W / W^{v}$ mice or the congenic normal $(+/+)$ mice, and the vehicle (HMEM/PIPES) was injected i.d. into the right ears. The swelling reactions were measured $30 \mathrm{~min}, 1,2,4,8$, and $24 \mathrm{~h}$ after injection. In $+/+$ mice, 1 or $5 \mathrm{nmol}$ of substance $P$ induced significant swelling responses which persisted for at least $8 \mathrm{~h}$ (Fig. 1). By contrast, no significant responses were detected in $\mathrm{WBB} \mathrm{F}_{1}-W / W^{v}$ mice (Fig. 1). Because the swelling reactions were largely dissipated by $4 \mathrm{~h}$ after injection, most of the subsequent studies were terminated at this interval.

We next tested $\mathrm{WCB} \mathrm{F}_{1-}+/+$ (normal) and $\mathrm{WCB} \mathrm{F}_{1}-\mathrm{Sl} /$ $S l^{d}$ mice, whose mast cell deficiency is the result of a mechanism distinct from that of $W / W^{v}$ mice (28-30). Substance P (1 $\mathrm{nmol} / \mathrm{site})$ produced swelling responses in $\mathrm{WCB} \mathrm{F}_{1^{-}}+/+$mice (Fig. 2) which were similar to those observed in $\mathrm{WBB} \mathrm{F}_{1^{-}}+/+$ mice (Fig. 1). By contrast, no significant responses were detected in $\mathrm{WCB} \mathrm{F}_{1}-\mathrm{Sl} / \mathrm{Sl}^{d}$ mice (Fig. 2).

Substance $P$ augments local extravasation of ${ }^{125} I-f i b r i n$ in $+/+$ but not $W / W^{v}$ mice. We previously reported that extravasation of ${ }^{125} \mathrm{I}$-fibrinogen and deposition of ${ }^{125} \mathrm{I}$-fibrin represented a very sensitive indicator of augmented cutaneous vascular permeability, which could detect contact sensitivity reactions too weak to be identified reliably by measurements of changes in ear thickness (32). We therefore used this assay to evaluate $2-\mathrm{h}$ reactions to injection of substance $\mathrm{P}$ in $W / W^{\nu}$ and congenic normal mice. The ear swelling responses in these mice were similar to those shown in Fig. 1, i.e., significant reactions to substance $P$ occurred in the $+/+$ but not the $W / W^{\nu}$ mice (Table I). In $+/+$ mice, the total ${ }^{125}$ I-fibrinogenrelated counts per minute in substance $P$-injected left ears exceeded the values in contralateral control (vehicle-injected ears) by a ratio of 3.4:1.0; the corresponding ratio for the urea insoluble ( ${ }^{125} \mathrm{I}$-fibrin-associated) counts per minute was 6.3:1.0 (Table I). By contrast, the total or urea insoluble ${ }^{125} I$ counts per 
Table I. Tissue Swelling and ${ }^{125}$ I-Species Derived from ${ }^{125}$ I-GPF after I.D. Injection of 1 nmol Substance P into Left $(L)$ Ears or Vehicle into Right (R) Ears of Mast Cell-deficient $W / W^{v}$ or Congenic Normal (+/+) Mice ${ }^{\ddagger}$

\begin{tabular}{|c|c|c|c|}
\hline & $\begin{array}{c}\text { A } \\
+/+\end{array}$ & $\underset{W / W^{v}}{\mathrm{~B}}$ & $\begin{array}{l}P \text { Value } \\
\text { A vs. B }\end{array}$ \\
\hline \multicolumn{4}{|c|}{ Ear swelling $\left(\Delta \times 10^{-4}\right.$ inch $)$} \\
\hline $1 \mathrm{~h} \mathrm{~L}$ & $56.8 \pm 6.6^{* \S}$ & $14.2 \pm 2.9$ & $<0.001$ \\
\hline $\mathbf{R}$ & $21.0 \pm 3.8$ & $13.6 \pm 3.2$ & NS \\
\hline $2 \mathrm{~h} \mathrm{~L}$ & $29.2 \pm 5.0^{* *}$ & $-1.8 \pm 1.9$ & $<0.001$ \\
\hline $\mathbf{R}$ & $12.6 \pm 5.0$ & $-1.2 \pm 4.1$ & NS" \\
\hline \multicolumn{4}{|c|}{${ }^{125} \mathrm{I}-\mathrm{GPF}$-derived cpm (2 h) } \\
\hline \multicolumn{4}{|c|}{ Total cpm } \\
\hline $\mathbf{L}$ & $15,998 \pm 1,132^{* * * *}$ & $4,344 \pm 420$ & $<0.02$ \\
\hline $\mathbf{R}$ & $4,717 \pm 391$ & $4,044 \pm 509$ & NS \\
\hline $\mathbf{L} / \mathbf{R}$ & 3.4 & 1.1 & \\
\hline \multicolumn{4}{|c|}{ Aqueous soluble cpm } \\
\hline $\mathbf{L}$ & $3,429 \pm 214^{* * *}$ & $1.769 \pm 61^{*}$ & $<0.02$ \\
\hline $\mathbf{R}$ & $1,619 \pm 55$ & $1,519 \pm 112$ & NS \\
\hline L/R & 2.1 & 1.2 & \\
\hline \multicolumn{4}{|c|}{ Urea soluble cpm } \\
\hline $\mathbf{L}$ & $930 \pm 57^{*}$ & $314 \pm 20$ & $<0.02$ \\
\hline $\mathbf{R}$ & $466 \pm 74$ & $299 \pm 59$ & NS \\
\hline L/R & 2.0 & 1.1 & \\
\hline \multicolumn{4}{|c|}{ Urea insoluble cpm } \\
\hline $\mathbf{L}$ & $8,563 \pm 848^{* * *}$ & $1,138 \pm 160$ & $<0.02$ \\
\hline $\mathbf{R}$ & $1,358 \pm 224$ & $1,297 \pm 155$ & NS \\
\hline $\mathbf{L} / \mathbf{R}$ & 6.3 & 0.9 & \\
\hline
\end{tabular}

₹ 20 min before intradermal challenge with substance $P$ or vehicle, the mice received ${ }^{125} \mathrm{I}$-GPF $\left(4.7 \times 10^{6} \mathrm{cpm} /\right.$ mouse i.v. $)$. Ear swelling was measured with a micrometer at 1 and $2 \mathrm{~h}$ after challenge, the mice were sacrificed at $2 \mathrm{~h}$ and the ears processed for analysis of the amount and pattern of solubility of ${ }^{125} \mathrm{I}$-GPF-derived cpm (see Methods). At the time of sacrifice, the ${ }^{125} \mathrm{I}-\mathrm{cpm}$ in $50 \mu 1$ PPP $=97,615 \pm 13,511$ for the $+/+$ mice and $98,615 \pm 4,918$ for $W / W^{\nu}$ mice. $\S$ Significant differences between values for $L$ and $R$ ears are indicated $\left({ }^{*} P<0.05,{ }^{* *} P<0.01,{ }^{* * *} P \leq 0.001\right)$.

"NS, not significant; $P>0.05$.

minute in the substance P-injected or control ears of $W / W^{v}$ mice were not significantly different (Table I). Indeed, the only significant difference between values in substance P-injected $(L)$ and control $(R)$ ears in $W / W^{\nu}$ mice was the $16 \%$ greater value for aqueous soluble counts per minute in the $L$ ears, a finding of uncertain biological significance.

Substance $P$-induced tissue swelling and granulocyte infiltration are associated with mast cell degranulation. The mice whose ear thickness measurements are shown in Fig. 1, were killed at $4,8,24$, or $48 \mathrm{~h}$ after substance $\mathrm{P}$ injection and the substance P-injected and contralateral control ears were processed for $1 \mu \mathrm{m}$, Epon-embedded Giemsa-stained sections. The sections were examined as previously described for assessment of the extent of mast cell degranulation and for quantitation of the number of granulocytes per square milliliter of dermis (37). In $\mathrm{WBB} \mathrm{F}_{1}-+/+$ mice, substance $\mathrm{P}$ elicited an infiltrate of leukocytes which consisted predominantly (>90\%) of neutrophils with much smaller numbers of eosinophils (generally $<5 \%$ of total leukocytes). The infiltrates were detectable $4 \mathrm{~h}$ after injection, increased slightly by $24 \mathrm{~h}$, and had resolved by $48 \mathrm{~h}$ (Fig. 3). The reactions were not impres-

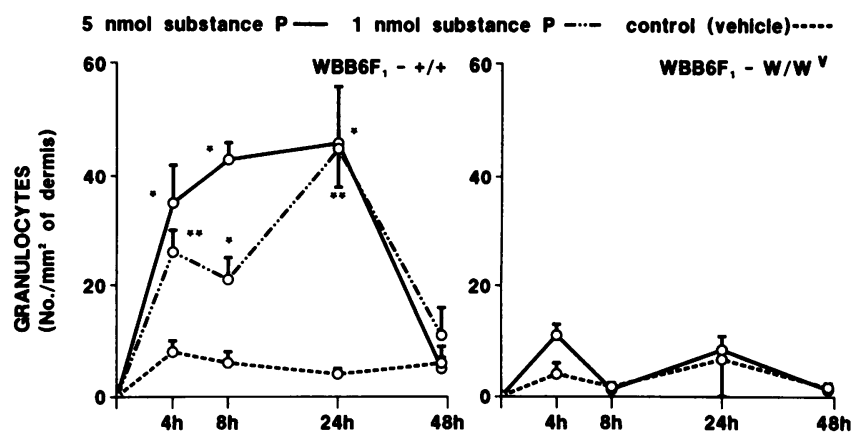

Figure 3. Granulocyte infiltration at sites of injection of 1 or $5 \mathrm{nmol}$ i.d. of substance $\mathrm{P}$ (L ears, $20 \mu \mathrm{l} /$ site in HMEM-PIPES) or vehicle alone ( $\mathrm{R}$ ears, $20 \mu$ l HMEM-PIPES/site) in $\mathrm{WBB} \mathrm{F}_{1}-+/+$ or $W / W^{\nu}$ mice. Data represent mean $\pm \operatorname{SEM}(n=3$ to $9 /$ point). Significant differences between values for $L$ and $R$ ears are shown as: ${ }^{*} P<0.05$, $* * P<0.01$

sive, however, with total leukocyte counts in substance P-injected sites exceeding those in contralateral control ears injected with vehicle by only $5-10$-fold. In $W / W^{v}$ mice, $5 \mathrm{nmol}$ (Fig. 3) or $1 \mathrm{nmol}$ (data not shown) of substance P-induced amounts of leukocyte infiltration that were not significantly different from those observed at contralateral control injection sites.

Substance $P$ induced extensive mast cell degranulation in $+/+$ mice, with the highest percentage of mast cells exhibiting extensive degranulation observed at the 4-h interval $(91.4 \pm 1.5 \%$ or $69.7 \pm 3.4 \%$ after injection of 5 or $1 \mathrm{nmol} / \mathrm{site}$, respectively). A reduction in the number of extensively degranulated mast cells seen at sites of substance $P$ injection at later intervals (e.g., $49.9 \pm 6.8 \%$ or $35.6 \pm 8.3 \% 24 \mathrm{~h}$ after 5 or 1 $\mathrm{nmol} / \mathrm{site}$, respectively), probably reflected partial recovery from activation. Examination of sites of vehicle injection revealed little or no mast cell degranulation $(0.6 \pm 0.3 \%$ or $1.5 \pm 1.5 \%$ extensively degranulated $4 \mathrm{~h}$ after 5 or $1 \mathrm{nmol} / \mathrm{site}$, respectively), but a minor population of cells did exhibit slight alterations of cytoplasmic granule morphology $(3.6 \pm 1.3 \%$ or $7.8 \pm 2.2 \% 4 \mathrm{~h}$ after 5 or $1 \mathrm{nmol} /$ site, respectively), perhaps related to the trauma of injection.

To establish the relationships among doses of substance $P$ and the extent of mast cell degranulation, tissue swelling, or leukocyte infiltration elicited, the left ears of additional WBB6F $_{1-}+/+$ mice were injected with 8,40 , or $200 \mathrm{pmol}$ of substance $P$, the swelling responses were recorded, and the mice were killed for histological analysis of the ears $4 \mathrm{~h}$ after injection. The data were pooled with those obtained from those $\mathrm{WBB} \mathrm{F}_{1}-+/+$ mice used in Fig. 3 which were killed $4 \mathrm{~h}$ after injection of 1 or $5 \mathrm{nmol}(1,000$ or $5,000 \mathrm{pmol})$ of substance $\mathbf{P}$ (Table II).

In these experiments, substance $P$ elicited a significant swelling response in $+/+$ mice when injected at $40 \mathrm{pmol} / \mathrm{site}$, whereas significant granulocyte infiltration was first observed at $200 \mathrm{pmol} / \mathrm{site}$. At the various doses of substance $P$ tested there were strong correlations between the extent of mast cell degranulation elicited and the tissue swelling ( $r=0.96, P$ $<0.02)$ or granulocyte infiltration $(r=0.88, P<0.05)$ observed, and also between the amounts of tissue swelling and granulocyte infiltration $(r=0.96, P<0.02)$. Even though a dose of $5 \mathrm{nmol}$ of substance $P$ produced more extensive mast cell degranulation than did 200 pmol $(91.4 \pm 1.5$ vs. $53.7 \pm 4.6 \%$ 
Table II. Tissue Swelling, Granulocyte Infiltration, and Mast Cell Degranulation in WBB6F $1^{-}+/+$Mice at Sites of Intradermal Injection of 8-5,000 pmol Substance P (L Ears) or Vehicle Alone (HMEM-PIPES, R Ears)

\begin{tabular}{|c|c|c|c|c|c|}
\hline \multirow[b]{2}{*}{ Characteristic of the reaction } & \multicolumn{5}{|c|}{ Dose of substance $P$} \\
\hline & 5,000 & 1,000 & 200 & 40 & 8 \\
\hline & \multicolumn{5}{|c|}{ pmol } \\
\hline $\begin{array}{l}\text { Ear swelling at } 1 \mathrm{~h}\left(\mathrm{~L}-\mathrm{R}, \times 10^{-4} / \mathrm{inch}\right)^{\ddagger} \\
\text { (No. of mice) }\end{array}$ & $\begin{array}{c}57.6 \pm 4.2^{* * * \neq} \\
(9)\end{array}$ & $\begin{array}{c}55.7 \pm 6.5^{* * *} \\
(6)\end{array}$ & $\begin{array}{c}55.0 \pm 6.7^{* * * *} \\
(9)\end{array}$ & $\begin{array}{l}14.1 \pm 3.1^{* *} \\
\quad(10)\end{array}$ & $\begin{array}{l}9.8 \pm 5.0 \\
(4)\end{array}$ \\
\hline \multicolumn{6}{|l|}{ Granulocytes $/ \mathrm{mm}^{2}$ dermis at $4 \mathrm{~h}^{\S}$} \\
\hline $\mathbf{L}$ & $35.0 \pm 7.1^{*}$ & $25.9 \pm 3.9^{* *}$ & $39.4 \pm 7.2^{* *}$ & $4.5 \pm 1.6$ & $1.4 \pm 0.6$ \\
\hline $\mathbf{R}$ & $7.7 \pm 2.6$ & $8.1 \pm 2.5$ & $4.5 \pm 1.5$ & $5.3 \pm 2.6$ & $2.3 \pm 1.0$ \\
\hline \multicolumn{6}{|l|}{ Mast cell degranulation at $4 h^{\S}$} \\
\hline \multicolumn{6}{|l|}{ Extensive (\%) } \\
\hline $\mathbf{L}$ & $91.4 \pm 1.5^{* * *}$ & $69.7 \pm 3.4^{* * *}$ & $53.7 \pm 4.6^{* * *}$ & $4.0 \pm 1.3$ & $0.0 \pm 0.0$ \\
\hline $\mathbf{R}$ & $0.6 \pm 0.3$ & $1.5 \pm 1.5$ & $1.4 \pm 0.4$ & $2.1 \pm 0.8$ & $1.5 \pm 0.6$ \\
\hline \multicolumn{6}{|l|}{ Slight/Moderate (\%) } \\
\hline $\mathbf{L}$ & $5.4 \pm 1.1$ & $14.0 \pm 1.8$ & $19.0 \pm 2.3^{*}$ & $9.6 \pm 1.8$ & $17.3 \pm 5.8$ \\
\hline $\mathbf{R}$ & $3.6 \pm 1.3$ & $7.8 \pm 2.2$ & $8.6 \pm 1.5$ & $6.9 \pm 1.4$ & $11.9 \pm 6.7$ \\
\hline \multicolumn{6}{|l|}{ None (\%) } \\
\hline $\mathbf{L}$ & $3.2 \pm 1.2^{* * *}$ & $16.3 \pm 2.6^{* * *}$ & $27.3 \pm 2.8^{* * *}$ & $86.4 \pm 2.7$ & $82.7 \pm 5.8$ \\
\hline $\mathbf{R}$ & $95.8 \pm 1.4$ & $90.7 \pm 2.8$ & $90.0 \pm 1.5$ & $91.0 \pm 1.7$ & $86.6 \pm 7.2$ \\
\hline
\end{tabular}

${ }^{\ddagger}$ For clarity, the swelling reaction to substance $P$ in each mouse was calculated as the $\Delta$ thickness ( $1 \mathrm{~h}$ postinjection value minus baseline value) for the substance $P$ injected $L$ ear minus the $\Delta$ thickness for the vehicle injected contralateral control $(R)$ ear, and values are shown as mean \pm SEM for each dose. ${ }^{\S}$ Significant differences between values for $\mathrm{L}$ and $\mathrm{R}$ ears are indicated $\left({ }^{*} P<0.05,{ }^{* *} P<0.01,{ }^{* * *} P<0.001\right)$.

"All mice were sacrificed at $4 \mathrm{~h}$ after injection for histological assessment of granulocyte infiltration and mast cell degranulation at the injection sites (see Methods).

extensively degranulated, $P<0.001$ ), these doses elicited similar amounts of tissue swelling and granulocyte infiltration. Thus, 200 pmol of substance $P$ was sufficient to elicit a near maximal response.

Six $\mathrm{WCB} \mathrm{F}_{1}-S l / S l^{d}$ mice and six congenic normal mice were also examined $4 \mathrm{~h}$ after injection of $1 \mathrm{pmol}$ of substance P. In $+/+$ mice, this dose of substance $P$ elicited extensive degranulation of $73.2 \pm 7.6 \%$ of the mast cells at the site, compared to $0.5 \pm 0.2 \%$ for the contralateral vehicle-injected ears $(P$ $<0.0003)$. The number of neutrophils in substance $P$ or vehicle-injected $+/+$ ears was $55.3 \pm 9.0$ vs. $4.0 \pm 1.5 / \mathrm{mm}^{2}$ of dermis $(P<0.002)$; the corresponding values for substance $P$ - or vehicle-injected ears in $S l / S l^{d}$ mice were $2.8 \pm 1.5$ vs. $3.0 \pm 1.3$ / $\mathrm{mm}^{2}$ (NS).

$W / W^{v}$ mice with adoptively transferred populations of dermal mast cells exhibit mast cell degranulation, augmented tissue swelling and vascular permeability, and granulocyte infitration at sites of substance $P$ injection. To evaluate whether the insensitivity of $W / W^{v}$ mouse skin to the effects of substance $P$ reflected this animal's mast cell deficiency, as opposed to other consequences of its mutations, we injected the neuropeptide into the mast cell-reconstituted (left) and contralateral control (mast cell-deficient) ears of $W / W^{\nu}$ mice which had received, at least $10 \mathrm{wk}$ earlier, an injection into the left ear of $0.5 \times 10^{6}$ culture-derived mast cells of $+/+$ bone marrow origin. Fig. 4 shows that $5 \mathrm{nmol}$ of substance $P$ elicited a swelling response in the mast cell-reconstituted ears that was significantly greater than that in the contralateral mast cell-deficient ears at all intervals up to $8 \mathrm{~h}$ after injection. Indeed, the responses in mast cell-reconstituted ears of $W / W^{v}$ mice were quite similar to those elicited when the same dose of substance $\mathbf{P}$ was injected into the ears of congenic $+/+$ mice (Fig. 1).
Table III shows the extent of mast cell degranulation, the swelling responses and the leukocyte infiltration elicited when various doses of substance $P$ were injected into the mast cell-

\section{5 nmol substance $P$ (to both ears)}

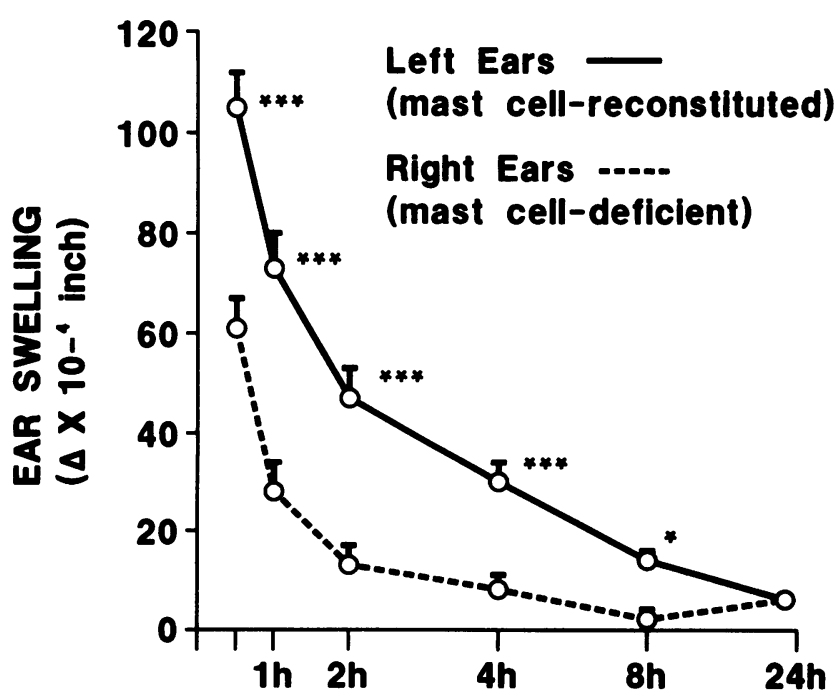

Figure 4. Ear swelling responses to $5 \mathrm{nmol}$ of substance $\mathrm{P}$ injected i.d. (in $20 \mu 1$ HMEM-PIPES) into both mast cell-reconstituted left ears, and mast cell-deficient right ears, of $W / W^{\nu}$ mice that received an injection, into the left ear, of $0.5 \times 10^{6}$ culture-derived, IL-3-dependent mast cells of congenic $+/+$ bone marrow origin $>10$ wk before the experiment (see Methods). Data represent mean $\pm \operatorname{SEM}(n$ $=7$ to 13/point). Significant differences between values for $L$ and $R$ ears are shown as: ${ }^{*} P<0.05,{ }^{* * *} P \leq 0.001$. 
Table III. Tissue Swelling, Granulocyte Infiltration, and Mast Cell Degranulation at Sites of Intradermal Injection of Various Doses of Substance P into the Left (L) Mast Cell-reconstituted and Right (R) Mast Cell-deficient Ears of W/Wv Mice That Had Been Locally Reconstituted with Mast Cells Derived from Congenic $+/+$ Bone Marrow Cells ${ }^{\ddagger}$

\begin{tabular}{|c|c|c|c|c|}
\hline \multirow[b]{2}{*}{ Characteristic of the reaction } & \multicolumn{4}{|c|}{ Dose of substance $P$} \\
\hline & 5,000 & 1,000 & 200 & 40 \\
\hline & \multicolumn{4}{|c|}{ pmol } \\
\hline \multicolumn{5}{|l|}{ Ear swelling at $1 \mathrm{~h}\left(\Delta \times 10^{-4} /\right.$ inch $)$} \\
\hline $30 \min \mathrm{L}$ & $123.7 \pm 7.5^{* * \S}$ & $133.5 \pm 8.7^{* *}$ & $88.0 \pm 12.1^{*}$ & $71.8 \pm 3.1^{* *}$ \\
\hline $\mathbf{R}$ & $74.2 \pm 9.3$ & $66.0 \pm 7.0$ & $59.8 \pm 9.7$ & $33.5 \pm 4.4$ \\
\hline $\mathbf{L}-\mathbf{R}$ & $49.5 \pm 8.9$ & $67.5 \pm 9.4$ & $28.2 \pm 9.1$ & $38.3 \pm 4.0$ \\
\hline $1 \mathrm{~h} \mathrm{~L}$ & $87.2 \pm 11.2^{*}$ & $102.5 \pm 7.0^{* *}$ & $56.8 \pm 8.4^{*}$ & $38.8 \pm 3.1^{*}$ \\
\hline $\mathbf{R}$ & $39.0 \pm 10.2$ & $31.8 \pm 6.6$ & $28.6 \pm 9.2$ & $10.3 \pm 7.1$ \\
\hline $\mathbf{L}-\mathbf{R}$ & $48.2 \pm 12.9$ & $70.8 \pm 8.8$ & $28.2 \pm 6.8$ & $28.5 \pm 8.7$ \\
\hline $2 \mathrm{~h} \mathrm{~L}$ & $60.7 \pm 9.8^{* *}$ & $73.5 \pm 7.6^{* *}$ & $29.8 \pm 7.0^{*}$ & $9.3 \pm 5.8$ \\
\hline $\mathbf{R}$ & $18.5 \pm 6.7$ & $20.8 \pm 5.9$ & $3.8 \pm 3.1$ & $-1.5 \pm 5.0$ \\
\hline $\mathbf{L}-\mathbf{R}$ & $42.2 \pm 9.15$ & $52.8 \pm 7.8$ & $26.0 \pm 6.1$ & $10.8 \pm 3.7$ \\
\hline \multicolumn{5}{|c|}{ Granulocytes $/ \mathrm{mm}^{2}$ dermis at 2 or $4 \mathrm{~h}$} \\
\hline $\mathbf{L}$ & $15.7 \pm 3.4^{* *}$ & $15.7 \pm 5.6$ & $18.8 \pm 6.1^{*}$ & $4.9 \pm 4.9$ \\
\hline $\mathbf{R}$ & $1.4 \pm 0.7$ & $2.5 \pm 0.9$ & $1.1 \pm 0.8$ & $0.8 \pm 0.8$ \\
\hline \multicolumn{5}{|l|}{ Mast cell (No./mm²) } \\
\hline $\mathbf{L}$ & $121.9 \pm 11.2^{* * *}$ & $89.0 \pm 8.1^{* *}$ & $77.1 \pm 9.0^{* *}$ & $67.0 \pm 16.5^{*}$ \\
\hline $\mathbf{R}$ & $0.0 \pm 0.0$ & $0.3 \pm 0.3$ & $1.4 \pm 1.0$ & $1.0 \pm 1.1$ \\
\hline \multicolumn{5}{|c|}{ Mast cell degranulation at 2 or $4 \mathrm{~h}$ (L ears) } \\
\hline Extensive (\%) & $86.2 \pm 2.5$ & $76.4 \pm 2.4$ & $17.2 \pm 7.3$ & $10.1 \pm 2.4$ \\
\hline Slight/moderate (\%) & $10.9 \pm 1.3$ & $12.9 \pm 0.9$ & $20.6 \pm 4.3$ & $32.9 \pm 3.4$ \\
\hline None $(\%)$ & $3.0 \pm 1.3$ & $10.7 \pm 2.3$ & $62.2 \pm 10.0$ & $57.0 \pm 1.4$ \\
\hline
\end{tabular}

₹ The left ears received an intradermal injection of $0.5 \times 10^{6}$ growth factor-dependent mast cells of $+/+$ bone marrow origin at least 10 wk before the experiment (see Methods). Substance P (in HMEM-PIPES) was injected into both ears, the swelling responses were assessed at various intervals thereafter, and the mice were killed for histological assessment of granulocyte infiltration, mast cell numbers, and extent of mast cell degranulation in injection sites $2 \mathrm{~h}(1,000$ or $40 \mathrm{pmol})$ or $4 \mathrm{~h}(5,000$ or $200 \mathrm{pmol})$ after injection. \$Significant differences between values for $\mathrm{L}$ and $\mathrm{R}$ ears are indicated $\left({ }^{*} P<0.05,{ }^{* *} P<0.01,{ }^{* * *} P<0.001\right)$.

reconstituted and contralateral mast cell-deficient ears of $W / W^{\nu}$ mice. As in $+/+$ mice, a significant swelling response was elicited in mast cell-reconstituted ears by 40 pmol of substance $P$, whereas significant neutrophil infiltration was observed at doses of $200 \mathrm{pmol}$ or more. The table also shows that the extent of mast cell degranulation increased with increasing doses of substance $P$, and that only the left ears of the mice were mast cell reconstituted. The number of mast cells at sites of substance $P$ injection in mast cell-reconstituted ears was $\sim 50 \%$ that in the ears of $+/+$ mice (mean values of 88 vs. 173 mast cells $/ \mathrm{mm}^{2}$ of dermis, No. of mice $=22-26$ ).

We also evaluated ${ }^{125} \mathrm{I}$-fibrinogen extravasation and ${ }^{125} \mathrm{I}$-fibrin deposition in mast cell reconstituted and contralateral mast cell-deficient ears injected with 1,000 pmol of substance P (Table IV). Significantly more total, aqueous soluble, urea soluble, and urea insoluble (cross-linked fibrin-associated) counts per minute were present in mast cell-reconstituted than in mast cell-deficient ears.

Effect of $\mathrm{Ca}^{2+}$ on the cutaneous mast cell degranulation and tissue swelling elicited by substance $P$. Studies of the effects of substance $P$ on isolated rat peritoneal mast cells indicate that mast cell degranulation by substance $P$ does not require extracellular calcium and actually is inhibited by levels of extracellular calcium in excess of $0.1 \mathrm{mM}$ (43). In addition, many previous evaluations of the effects of intradermal substance $P$ were based on analyses of the peptide injected in $\mathrm{Ca}^{2+}$-free vehicle $(4-8,11)$. We therefore compared the responses of WBB6F $_{1}-+/+$ mice to injections of low doses of substance $P$ solubilized either in HBSS lacking $\mathrm{Ca}^{2+}$ and $\mathrm{Mg}^{2+}\left(-\mathrm{Ca}^{2+}\right)$ or in $\mathrm{HBSS}$ with $1.3 \mathrm{mM} \mathrm{Ca}^{2+}\left(+\mathrm{Ca}^{2+}\right)$, the same concentration of $\mathrm{Ca}^{2+}$ present in the HMEM-PIPES used in our other experiments.

Swelling reactions to 8 or 40 pmol of substance $P$ administered without $\mathrm{Ca}^{2+}$ were significantly greater than those elicited by the same doses given in medium containing $1.3 \mathrm{mM}$ $\mathrm{Ca}^{2+}$ (e.g., at $8 \mathrm{pmol} / \mathrm{site}, 21.6 \pm 2.7 \times 10^{-4}$ inch with $\mathrm{Ca}^{2+}$ vs. $40.3 \pm 5.5$ without $\left.\mathrm{Ca}^{2+}, P<0.02\right)$. Notably, however, "control" swelling responses in right ears injected solely with medium lacking $\mathrm{Ca}^{2+}$ and $\mathrm{Mg}^{2+}$ were also slightly, but in several instances significantly, greater than those in ears injected with medium containing $1.3 \mathrm{mM} \mathrm{Ca}^{2+}$ (e.g., $9.9 \pm 2.1$ vs. $25.3+5.2$ $\times 10^{-4}$ inch with or without $\mathrm{Ca}^{2+}$, respectively, $P<0.02$ ). As a result, when the intensity of the reactions to substance $P$ were expressed as the difference between values in $L$ (substance P-injected) and R (vehicle-injected) ears, most of the comparisons between the swelling reactions elicited in the presence or absence of $1.3 \mathrm{mM} \mathrm{Ca}^{2+}$ failed to achieve statistical significance. In fact, at 2 pmol of substance $P$, the swelling reactions 1 or $2 \mathrm{~h}$ after injection of substance $\mathrm{P}$ ( $\mathrm{L}$ ears) were significantly $(P<0.05)$ greater than those in vehicle-injected $(R)$ ears when $\mathrm{Ca}^{2+}$ was included in the injectate $(L-R=6.4 \pm 2.2$ or $3.6 \pm 1.0 \times 10^{-4}$ inch, at 1 or $2 \mathrm{~h}$, respectively), but did not 
Table IV. Tissue Swelling and ${ }^{125}$ I-species Derived from ${ }^{125}$ I-GPF after Intradermal Injection of 1 nmol Substance P into the Left (L) Mast Cell-reconstituted and Right (R) Mast Cell-deficient Ears of $W / W^{\nu}$ Mice That Had Been Locally Reconstituted with Mast Cells Derived from Congenic $+/+$ Bone Marrow Cells ${ }^{\ddagger}$

\begin{tabular}{|c|c|c|c|c|}
\hline & $\begin{array}{c}(A) \mathrm{L} \text { ears } \\
\text { (mast cell-reconstituted) }\end{array}$ & $\begin{array}{c}(B) \mathrm{R} \text { ears } \\
\text { (mast cell-deficient) }\end{array}$ & $L / R$ & $\begin{array}{l}P \text { Value, } \\
\text { A vs. B }\end{array}$ \\
\hline \multicolumn{5}{|c|}{ Ear swelling $\left(\Delta \times 10^{-4}\right.$ inch $)$} \\
\hline $1 \mathrm{~h}$ & $102.5 \pm 7.0$ & $31.8 \pm 6.6$ & 3.2 & $<0.005$ \\
\hline $2 \mathrm{~h}$ & $73.5 \pm 7.6$ & $20.8 \pm 5.9$ & 3.5 & $<0.007$ \\
\hline \multicolumn{5}{|c|}{${ }^{125}$ I-GPF-derived cpm $(2 h)$} \\
\hline Total cpm & $23,340 \pm 3,041$ & $10,061 \pm 1,161$ & 2.3 & $<0.02$ \\
\hline Aqueous soluble cpm & $5,482 \pm 603$ & $3,015 \pm 218$ & 1.8 & $<0.01$ \\
\hline Urea soluble cpm & $1,387 \pm 120$ & $558 \pm 68$ & 2.5 & $<0.003$ \\
\hline Urea insoluble cpm & $11,181 \pm 2,115$ & $3,200 \pm 486$ & 3.5 & $<0.03$ \\
\hline
\end{tabular}

₹ The left ears of these four mice received an intradermal injection of $0.5 \times 10^{6}$ growth factor-dependent mast cells of $+/+$ bone marrow origin at least $10 \mathrm{wk}$ before the experiment (see Methods). $20 \mathrm{~min}$ before challenge of both ears with substance $P$ in HMEM-PIPES, the mice received ${ }^{125} \mathrm{I}$-GPF $\left(4.7 \times 10^{6} \mathrm{cpm}\right.$ i.v.). Ear swelling was measured with a micrometer at various intervals after challenge, the mice were killed at $2 \mathrm{~h}$, and the ears were processed for analysis of the amount and pattern of solubility of ${ }^{125}$ I-GPF-derived cpm (see Methods). At the time of sacrifice, the ${ }^{125} \mathrm{I}-\mathrm{cpm}$ in $50 \mu \mathrm{l}$ PPP $=80,847 \pm 6,408 \mathrm{cpm}$. The histological findings in these mice are included in Table III.

achieve statistical significance when $\mathrm{Ca}^{2+}$ was omitted (L-R $=0.1 \pm 36$ or $2.4 \pm 2.5 \times 10^{-4}$ inch at 1 or $2 \mathrm{~h}$, respectively). This result reflected the larger control reactions in right ears injected with $\mathrm{Ca}^{2+}$-free as opposed to $\mathrm{Ca}^{2+}$-containing vehicle.

Histological analysis indicated that mast cell degranulation at sites of injection of substance $P$ was greater when the neuropeptide was injected in medium lacking $\mathrm{Ca}^{2+}$, but that control sites injected with $\mathrm{Ca}^{2+}$-free vehicle alone also exhibited more mast cell activation than did corresponding control sites injected with medium containing $1.3 \mathrm{mM} \mathrm{Ca}^{2+}$. For example, in the $L$ ears of mice injected with 8 pmol substance $P$, the values for extensively degranulated mast cells were $2.1 \pm 0.6 \%\left(+\mathrm{Ca}^{2+}\right)$ vs. $16.2 \pm 4.0 \%\left(-\mathrm{Ca}^{2+}\right), P<0.005$, while the values for vehicle-injected $\mathrm{R}$ ears were $0.8 \pm 0.4 \%\left(+\mathrm{Ca}^{2+}\right)$ vs. $4.8 \pm 1.3 \%$ $\left(-\mathrm{Ca}^{2+}\right), P<0.02$. Little or no neutrophil infiltration occurred at sites of injection of 2,8 , or $40 \mathrm{pmol}$ of substance $P$, whether or not the vehicle contained $\mathrm{Ca}^{2+}$ (mean values $=0.2-9.3$ granulocytes $/ \mathrm{mm}^{2}$ of dermis at $4 \mathrm{~h}$ in substance P-injected ears, NS vs. values for contralateral vehicle-injected ears).

Assessment of the activity of peptides structurally related to substance $P$. Studies of rat peritoneal mast cells in vitro indicate that the basic amino acid residues in the $\mathrm{NH}_{2}$-terminal sequence of substance $P$ are essential for its ability to cause histamine release, but that binding of substance $P$ to the mast cells is dependent on the $\mathrm{COOH}$-terminal portion of the molecule $(8,43,44)$. Thus, substance $P_{1-4}$ was substantially less active than native substance $P_{1-11}$ in releasing histamine from rat peritoneal mast cells, whereas the $\mathrm{COOH}$-terminal heptapeptide or octapeptide (substance $\mathbf{P}_{4-11}$ ) was inactive in this assay system $(8,43,44)$. By contrast, substance $P_{1-4}$ was inactive in doses up to $12.5 \mathrm{nmol} / \mathrm{site}$ when tested for its ability to induce alterations of vascular permeability (a wheal) in human skin, whereas substance $P_{4-11}$ had $40 \%$ of the activity of substance $P_{1-11}$ in this system (8). The latter result indicates that while substance $P_{4-11}$ is inactive as a histamine-releasing agent when tested against purified rat peritoneal mast cells in vitro, it is able to induce alterations in vascular permeability when administered to human skin in vivo.

We quantitated the effects of substance $P_{1-4}$ or substance $\mathbf{P}_{4-11}$ on cutaneous mast cell degranulation, tissue swelling, and leukocyte infiltration after injection of these peptides into the skin of $\mathrm{WBB} \mathrm{F}_{1}-+/+$ mice. As shown in Table $\mathrm{V}$, substance $P_{1-4}$ had no detectable activity when administered at a dose of $25 \mathrm{nmol}$. By contrast, substance $P_{4-11}$ produced significant tissue swelling responses in both $W / W^{\nu}$ and congenic $+/+$ mice. At each dose of substance $\mathbf{P}_{4-11}$ tested, swelling responses were greater in $+/+$ than in $W / W^{v}$ mice. However, these differences did not achieve statistical significance. On the other hand, substance $\mathbf{P}_{4-11}$ elicited significantly more granulocyte infiltration in $+/+$ mice than in $W / W^{v}$ mice, an effect that may have been related to the slight mast cell activation observed at sites of injection of this agent in $+/+$ skin. Based on comparison with data obtained when substance $P_{1-11}$ was injected in $\mathrm{Ca}^{2+} / \mathrm{Mg}^{2+}$-free medium, $5 \mathrm{nmol}$ of substance $\mathrm{P}_{4-11}$ produced an amount of mast cell degranulation (18.4 $\pm 2.6 \%$ extensively degranulated) and tissue swelling $\left(34.6 \pm 5.9 \times 10^{-4}\right.$ inch at $1 \mathrm{~h}$ ) roughly the same as that elicited by $40 \mathrm{pmol}$ of substance $P_{1-11}(18.8 \pm 4.7 \%$ extensively degranulated mast cells, swelling of $44.8 \pm 6.7 \times 10^{-4}$ at $1 \mathrm{~h}$ ).

\section{Discussion}

We found that virtually all of the tissue swelling, augmentation of interstitial ${ }^{125}$ I-fibrin deposition, and leukocyte infiltration that followed intradermal injection of substance $P$ into mouse skin was mast cell-dependent. Indeed, injection of up to 5 nmol of substance $P$ into the skin of genetically mast cell-deficient $W / W^{\nu}$ or $S l / S l^{d}$ mice produced effects which were little or no different than those observed after injection of vehicle alone. By contrast, injection of as little as 2 pmol of substance $P$ into $+/+$ mice induced significant cutaneous swelling. Thus, normal mice are at least 1,000 -fold more sensitive to the vascular permeability-enhancing effects of substance $P$ than are the congenic mast cell-deficient mice.

Two lines of evidence support the conclusion that the substance P-induced tissue swelling and leukocyte infiltration observed in our study were largely mast cell-dependent. First, when various doses of substance $P(8-5,000 \mathrm{pmol})$ were tested in $\mathrm{WBB} \mathrm{F}_{1^{-}}+/+$mice, there was an excellent correlation between the extent of mast cell degranulation at the sites of in- 
Table V. Tissue Swelling, Granulocyte Infiltration and Mast Cell Degranulation in $W B B 6 F_{1}-W / W^{v}$ or $+/+$ Mice at Sites of I.D. Injection of Substance $P_{1-4}\left(S P_{1-4}\right)$ or Substance $P_{4-11}\left(S P_{4-11}\right)^{\ddagger}$

\begin{tabular}{|c|c|c|c|c|}
\hline \multirow[b]{2}{*}{ Characteristic of the reaction } & \multicolumn{4}{|c|}{ Agent } \\
\hline & $\begin{array}{l}\mathrm{SP}_{1-4} \\
\text { (25) }\end{array}$ & $\begin{array}{l}\mathrm{SP}_{4-11} \\
(25)\end{array}$ & $\begin{array}{c}\mathrm{SP}_{4-11} \\
\text { (5) }\end{array}$ & $\begin{array}{c}\mathbf{S P}_{4-11} \\
\text { (1) }\end{array}$ \\
\hline & \multicolumn{4}{|c|}{ dose, $n m o l$} \\
\hline \multicolumn{5}{|c|}{ Ear swelling at $1 \mathrm{~h}\left(\mathrm{~L}-\mathrm{R}, \times 10^{-4} \text { inch }\right)^{8}$} \\
\hline$+/+$ & $1.3 \pm 3.8$ & $40.0 \pm 6.4^{* \|}$ & $34.6 \pm 5.9^{* *}$ & $21.4 \pm 3.2^{* *}$ \\
\hline$W / W^{\nu}$ & ND & $24.2 \pm 5.6^{*}$ & $26.8 \pm 4.4^{* *}$ & $13.6 \pm 4.0^{*}$ \\
\hline$P$ value,$+/+$ vs. $W / W^{v}$ & - & $N^{1}$ & NS & NS \\
\hline \multicolumn{5}{|l|}{ Granulocytes $/ \mathrm{mm}^{2}$ dermis at $4 \mathrm{~h}^{\ddagger \ddagger}$} \\
\hline$+/+$ & $0.4 \pm 0.4$ & $17.3 \pm 4.9$ & $24.3 \pm 7.2$ & $25.9 \pm 5.2$ \\
\hline$W / W^{\nu}$ & $\mathrm{ND}^{\$ S}$ & $1.9 \pm 1.4$ & $1.6 \pm 1.0$ & ND \\
\hline$P$ value, $+/+$ vs. $W / W^{\nu}$ & - & $<0.02$ & $<0.02$ & - \\
\hline \multicolumn{5}{|l|}{ Mast cell degranulation at $4 \mathrm{~h}^{\ddagger \ddagger}$} \\
\hline \multicolumn{5}{|l|}{$(+/+$ mice $)$} \\
\hline Extensive (\%) & $0.7 \pm 0.7$ & $24.5 \pm 3.1$ & $18.4 \pm 2.6$ & $17.4 \pm 3.7$ \\
\hline Slight/moderate (\%) & $8.6 \pm 2.2$ & $12.1 \pm 2.3$ & $17.0 \pm 2.6$ & $19.4 \pm 1.7$ \\
\hline None (\%) & $90.7 \pm 2.2$ & $63.4 \pm 5.0$ & $64.6 \pm 4.6$ & $63.2 \pm 4.5$ \\
\hline
\end{tabular}

${ }^{\ddagger}$ Left ears received substance $\mathrm{P}_{1-4}$ or substance $\mathrm{P}_{4-11}$ in $\mathrm{Ca}^{2+} / \mathrm{Mg}^{2+}$-free $\mathrm{HBSS}$, right ears received $\mathrm{Ca}^{2+} / \mathrm{Mg}^{2+}$-free $\mathrm{HBSS}$. ${ }^{\S}$ For clarity, the swelling reaction to substance $P$ in each mouse was calculated as the $\Delta$ thickness $(1 \mathrm{~h}$ post injection value minus baseline value) for the substance $P$ injected $L$ ear minus the $\Delta$ thickness for the vehicle injected contralateral control $(R)$ ear, and values are shown as mean \pm SEM for each dose. "Significant differences between values for $\mathrm{L}$ and $\mathrm{R}$ ears are indicated $\left({ }^{*} P<0.05,{ }^{* *} P<0.01,{ }^{* * *} P<0.001\right)$. ' $\mathrm{NS}$, not significant, $P>0.05$. ${ }^{\sharp}$ All mice were sacrificed at $4 \mathrm{~h}$ after injection for histological assessment of granulocyte infiltration and mast cell degranulation at the injection sites (see Methods). Values shown are for $\mathrm{L}$ (peptide injected) ears. ${ }^{\S} \mathrm{ND}$, not done.

jection and the tissue swelling $(r=0.96, P<0.02)$ or granulocyte infiltration $(r=0.88, P<0.05)$ observed at those sites. Second, when substance $P$ was injected into both the mast cell-reconstituted and contralateral mast cell-deficient ears of the same $W / W^{v}$ mice, the reactions were always significantly greater in the mast cell-reconstituted ears. This was true even though the substance $P$ injection sites in ears locally reconstituted with mast cells contained only $\sim 50 \%$ of the mast cells present in corresponding sites in $+/+$ mice. Thus, the experiments in $W / W^{v}$ mice locally reconstituted with mast cells actually may have underestimated the potential contribution of mast cells to these reactions in normal mice.

We found that the effects of substance $P$ on cutaneous vascular permeability occurred sooner and at lower doses of peptide than did effects on leukocyte infiltration. Moreover, the intensity of leukocyte infiltration induced by substance $P$ was quite modest compared to that seen with other stimuli, and even this weak effect required injection of large amounts of substance $P$. For example, the number of neutrophils at sites of $\mathrm{WBB} \mathrm{F}_{1}-+/+$ skin injected $24 \mathrm{~h}$ previously with $5 \mathrm{nmol}$ of substance $P$ was $46 \pm 10 / \mathrm{mm}^{2}$, a value that was only $\sim 10$ times that in the contralateral control ears injected with vehicle and only $\sim 1.2 \%$ of the value at similar sites treated epicutaneously with $10 \mu \mathrm{g}$ phorbol 12 -myristate 13 -acetate (PMA) (37). By contrast, the tissue swelling attributable to $5 \mathrm{nmol}$ substance $P$ ( $1 \mathrm{~h}$ after challenge in $\mathrm{WBB} \mathrm{F}_{1}-+/+$ mice) was $\sim 40 \%$ that induced by PMA ( $6 \mathrm{~h}$ after challenge, reference 37). Thus, even though the cutaneous granulocyte infiltration that follows intradermal injection of substance $P$, like that observed by Matsuda et al. in the tissue surrounding subcuta- neous air pouches injected with the peptide (27), was largely mast cell dependent, this represented a relatively weak effect of the peptide compared with its ability to augment vascular permeability.

Previous work indicated that substance P-induced mast cell degranulation did not require extracellular calcium and was inhibited when levels of extracellular calcium exceeded $0.1 \mathrm{mM}(8,43,44)$. We found that substance $P$ induced significantly greater swelling and mast cell degranulation when injected into mouse skin at 2,8 , or $40 \mathrm{pmol} / \mathrm{site}$ in $\mathrm{Ca}^{2+}$-free medium than in medium containing $1.3 \mathrm{mM} \mathrm{Ca}^{2+}$. However, we also found that $\mathrm{Ca}^{2+}$-free medium itself caused slightly, but significantly, more swelling than did the same medium containing $1.3 \mathrm{mM} \mathrm{Ca}{ }^{2+}$. Moreover, histological analysis indicated that the latter effect probably reflected slight mast cell degranulation at sites of injection of $\mathrm{Ca}^{2+}$-free medium. While the mechanism responsible for the higher level of nonspecific mast cell activation observed at control sites injected with $\mathrm{Ca}^{2+}$-free medium is not clear, this phenomenon may obscure detection of very weak reactions elicited by low doses of substance $\mathbf{P}$ or other agents injected in vehicles lacking $\mathrm{Ca}^{2+}$. Thus, we detected a weak but significant response to $2 \mathrm{pmol}$ of substance $\mathbf{P}$ injected in $\mathrm{Ca}^{2+}$-containing medium, but did not detect a significant response to the same dose of substance $P$ administered in $\mathrm{Ca}^{2+}$-free medium.

In accord with previous studies in other species $(8,43,44)$, we found that the $\mathrm{NH}_{2}$-terminal tetrapeptide of substance $P$, substance $P_{1-4}$, had no significant ability to augment cutaneous vascular permeability. Nor did it induce significant cutaneous mast cell degranulation when injected at $25 \mathrm{nmol} / \mathrm{site}$, a 
dose $>3,000$ times higher than the amount of substance $P_{1-11}$ ( $8 \mathrm{pmol} / \mathrm{site}$ ) required to elicit significant mast cell degranulation. When the $\mathrm{COOH}$-terminal octapeptide substance $\mathbf{P}_{4-11}$ was tested, it induced augmented vascular permeability in both mast cell-deficient and congenic $+/+$ mice, suggesting that the ability of this peptide to induce a wheal in human skin (8) may be at least in part a mast cell-independent effect. However, the peptide did induce more granulocyte infiltration in $+/+$ than in $W / W^{v}$ mice, and modest but significant mast cell degranulation was detected at injection sites.

The fact that the intradermal injection of substance $P_{4-11}$ resulted in degranulation of cutaneous mast cells when tested at doses similar to those which did not induce degranulation of rat peritoneal mast cells in vitro (8) is of interest. However, we do not feel that this finding should necessarily be considered a contradiction of the relationships between the structure of substance P-related peptides and their abilities to activate mast cells that were established on the basis of in vitro studies. First, substance $P_{4-11}$ was substantially less potent in inducing mast cell degranulation than was the native peptide. $1 \mathrm{nmol}$ of substance $P_{4-11}$ induced approximately the same amount of mast cell degranulation as $8 \mathrm{pmol}$ of substance $P_{1-11}(17.4 \pm 3.7$ vs. $16.2 \pm 4.0 \%$ extensively degranulated) and increasing the dose of substance $P_{4-11}$ to $25 \mathrm{nmol}$ resulted in little additional effect (24.5 $\pm 3.1 \%$ extensively degranulated). By contrast, substance $P_{1-11}$ at 0.2 or $5 \mathrm{nmol} / \mathrm{site}$ induced extensive degranulation of $53.7 \pm 4.6$ or $91.4 \pm 1.5 \%$ of mast cells. Second, the in vivo system we used would not be able to distinguish between direct activation of cutaneous mast cells by substance $P$ and related peptides, whether by receptor-mediated or other mechanisms, as opposed to indirect activation of mast cells as a result of other local changes (e.g., complement activation) induced at sites of peptide injection. Such indirect mechanisms of mast cell activation may have been triggered in association with or as a result of the ability of substance $P_{4-11}$ to augment vascular permeability independently of the mast cell.

Similarly, the results presented here are not incompatible with evidence that important mast cell-independent effects of substance $\mathbf{P}$ or other neuropeptides can be observed under different circumstances. For example, Kowalski and Kaliner showed that ES can induce an apparently mast cell-independent augmentation of vascular permeability in the rat which is detectable immediately (within a few minutes) after stimulation (13). The procedure employed in our study is not well suited for identifying neuropeptide-dependent changes induced within a few minutes of challenge, since the intradermal injection of $20 \mu \mathrm{l}$ of fluid itself causes an increase in ear thickness during this interval. Kowalski et al. also showed that $W / W^{\nu}$ and $+/+$ mice exhibit indistinguishable alterations in vascular permeability in response to intravenous substance $P^{2}{ }^{2}$ This observation is compatible with the finding that the vasodilatory effects of intraarterial substance $P$ in human skin (26), unlike the effects induced by intradermal administration of the peptide $(4-8,11)$, are not inhibited by antihistamines. Taken together with our results, these findings indicate that the extent to which the vascular effects of substance $\mathbf{P}$ are mast cell-dependent may be critically influenced by the route of administration of the peptide. For example, intravenous or intraarterial administration favors direct interactions with vascular endothelial cells, whereas intradermal injection facilitates interactions with interstitial elements such as mast cells.
In fact it should be emphasized that our experiments, like many previous reports, specifically evaluated the effects of the intradermal injection of substance $P$ and related peptides, not the release of peptides from endogenous sources. While our results certainly are consistent with the possibility that some of the local consequences of substance $P$ release by peptidergic nerves are mast cell dependent, they by no means prove that this is so. Identifying the extent of the mast cell's actual contributions to the local consequences of endogenous neuropeptide release in various tissues and organs represents a potentially important but difficult challenge for future work. Indeed, it should be appreciated that the reactions induced by substance $P$ and other neuropeptides that can activate mast cells are likely to be under complex regulatory control in vivo. The effects observed in particular organs or tissues will depend on such factors as the concentration of endogenous neuropeptide that might be achieved in the immediate vicinity of its release, the proximity of mast cells to sites of neuropeptide release, the sensitivity of that particular mast cell population to activation (directly or indirectly) by neuropeptide-dependent mechanisms, and the local distribution and activity of enzymes capable of degrading the neuropeptides $(45,46)$. Many (perhaps all) of these factors exhibit considerable species and anatomical variation (reviewed in 8, 14-16, 46, 47).

Nevertheless, our findings indicate that virtually all of substance P's ability to elicit cutaneous swelling and leukocyte infiltration upon intradermal injection into mouse skin is mast cell dependent. This result, taken together with evidence indicating that human cutaneous mast cells are particularly sensitive to stimulation by substance $P(4,5-8,10-12,15,16)$, suggests that the wheal component of the response to intradermal injection of substance $P$ in human skin might represent a mast cell-dependent effect of the peptide, not a direct action of substance $P$ on the vasculature. Thus, even though antihistamines are much more effective in blocking the flare, rather than the wheal, induced by intradermal substance $P(4,8-11)$, this might simply reflect the relative importance of histamine release, as opposed to other consequences of mast cell activation, in these two components of the response $(11,15,16)$.

\section{Acknowledgments}

We thank Norma S. Gerard, Beth Israel Hospital and Harvard Medical School, Michael A. Kaliner, National Institutes of Health, Hiroshi Matsuda, University of Osaka Prefecture, and Yukihiko Kitamura, Osaka University, for valuable discussions.

This work was supported in part by U. S. Public Health Service grants AI-22674, AI-23990, and Physician-Scientist Award K11 DK-01543 (to B. K. Wershil). The animal experiments were conducted in accordance with the Beth Israel Hospital's Committee on Animal Research and with guidelines prepared by the Committee on the Care and Use of Laboratory Animals of the Institute of Laboratory Animal Resources, National Research Council (DHHS publication No. 86-23, revised 1985).

\section{References}

1. Kiernan, J. A. 1972. The involvement of mast cells in vasodilatation due to axon reflex in injured skin. Q.J. Exp. Physiol. 57:311317.

2. Kiernan, J. A. 1977. Study of chemically induced acute inflammation in the skin of the rat. Q. J. Exp. Physiol. 62:151-156. 
3. Johnson, A. R., and E. G. Erdös. 1973. Release of histamine from mast cells by vasoactive peptides. Proc. Soc. Exp. Biol. Med. 142:1252-1256.

4. Hägermark, O., T. Hökfelt, and B. Pernow. 1978. Flare and itch induced by substance P in human skin. J. Invest. Dermatol. 71:233235.

5. Fjellner, B., and Ö. Hägermark. 1981. Studies on pruritogenic and histamine-releasing effects of some putative peptide neurotransmitters. Acta Dermatovener (Stockh.) 61:245-250.

6. Foreman, J. C., and C. C. Jordan. 1981. Comparison of the activities of some peptides in human skin and as histamine releasing agents. Br. J. Pharmacol. 73:207P.

7. Foreman, J. C., C. C. Jordan, P. Oehme, and H. Renner. 1983. Structure-activity relationships for some substance P-related peptides that cause wheal and flare reactions in human skin. J. Physiol. (Lond.). 335:449-465.

8. Foreman, J. C., and C. C. Jordan. 1983. Histamine release and vascular changes induced by neuropeptides. Agents Actions. 13:105116.

9. Shanahan, F., J. A. Deneburg, J. Fox, J. Bienenstock, and D. Befus. 1985. Mast cell heterogeneity: effects of neuroenteric peptides on histamine release. J. Immunol. 135:1331-1337.

10. Ebertz, J. M., C. A. Hirshman, N. S. Kettelkamp, H. Uno, and J. M. Hanifin. 1987. Substance P-induced histamine release in human cutaneous mast cells. J. Invest. Dermatol. 88:682-685.

11. Foreman, J. C. 1987. Substance $P$ and calcitonin gene-related peptide: effects on mast cells and in human skin. Int. Arch. Allergy Appl. Immunol. 82:366-371.

12. Lawrence, I. D., J. A. Warner, V. L. Cohan, W. C. Hubbard, A. Kagey-Sobotka, and L. M. Lichtenstein. 1987. Purification and characterization of human skin mast cells. Evidence for human mast cell heterogeneity. J. Immunol. 139:3062-3069.

13. Kowalski, M. L., and M. L. Kaliner. 1988. Neurogenic inflammation, vascular permeability, and mast cells. J. Immunol. 140:39053911.

14. Stead, R. H., M. H. Perdue, M. G. Blennerhassett, Y. Kakuta, P. Sestini, and J. Bienenstock. The innervation of mast cells. In The Neuroendocrine-Immune Network. S. Freier, editor. CRC Press, Boca Raton, FL. In press.

15. Church, M. K., R. C. Benyon, P. H. Rees, M. A. Lowman, A. M. Campbell, C. Robinson, and S. T. Holgate. 1989. Functional heterogeneity of human mast cells. In Mast cell and Basophil Differentiation and Function in Health and Disease. S. J. Galli and K. F. Austen, editors. Raven Press, New York. 161-170.

16. Cohan, V. L., W. A. Massey, S. D. Gittlen, E. N. Charlesworth, J. A. Warner, A. Kagey-Sobotka, L. M. Lichtenstein. 1989. The heterogeneity of human histamine containing cells. In Mast cell and Basophil Differentiation and Function in Health and Disease. S. J. Galli and K. F. Austen, editors. Raven Press, New York. 149-159.

17. Wiesner-Menzel, L., B. Schulz, F. Vakilzadeh, and B. M. Czarnetzki. 1981. Electron microscopical evidence for a direct contact between nerve fibers and mast cells. Acta Dermatol. Venerol. (Stockh.). 61:465-469.

18. Newson, B., A. Dählström, L. Enerbäck, and H. Ahlman. 1983. Suggestive evidence for a direct innervation of mucosal mast cells. An electron microscopic study. Neuroscience. 10:565-570.

19. Skofitsch, G., J. M. Savitt, and D. M. Jacobovitz. 1985. Suggestive evidence for a functional unit between mast cells and substance $P$ fibers in the rat diaphragm and mesentery. Histochemistry. 82:5-8.

20. Stead, R. H., M. Tomioka, G. Quinonez, G. T. Simon, S. Y. Felten, and J. Bienenstock. 1987. Intestinal mucosal mast cells in normal and nematode-infected rat intestines are in intimate contact with peptidergic nerves. Proc. Natl. Acad. Sci. USA. 84:2975-2979.

21. Lembeck, F., and P. Holzer. 1979. Substance $P$ as neurogenic mediator of antidromic vasodilatation and neurogenic plasma extravasation. Naunyn-Schmiedeberg's Arch. Pharmacol. 310:175-183.

22. Couture, R., and A. C. Cuello. 1984. Studies on the trigeminal antidromic vasodilatation and plasma extravasation in the rat. $J$. Physiol. 346:273-285.

23. Jancsó, N., A. Jancsó-Gábor, and J. Szolcsányi. 1967. Direct evidence for neurogenic inflammation and its prevention by denervation and by pretreatment with capsaicin. Br. J. Pharmacol. Chemother. 31:138-151.

24. Gamse, R., and A. Saria. 1987. Antidromic vasodilatation in the rat hindpaw measured by laser Doppler flowmetry: pharmacological modulation. J. Auton. Nerve. Syst. 19:105-111.

25. Lundberg, J. M., A. Saria, S. Rosell, and K. Folkers. 1984. A substance $\mathbf{P}$ antagonist inhibits heat-induced oedema in the rat skin. Acta Physiol. Scand. 120:145-146.

26. Löfström, B., B. Pernow, and J. Wahren. 1965. Vasodilating action of substance $\mathrm{P}$ in human forearm. Acta Physiol. Scand. 63:311-324.

27. Matsuda, H., K. Kawakita, Y. Kiso, T. Nakano, and Y. Kitamura. 1989. Substance $P$ induces granulocyte infiltration through degranulation of mast cells. J. Immunol. 142:927-931.

28. Kitamura, Y. S., S. Go, and S. Hatanaka. 1978. Decrease of mast cells in $W / W^{v}$ mice and their increase by bone marrow transplantation. Blood. 52:447-452.

29. Kitamura, Y. S., and S. Go. 1979. Decreased production of mast cells in $S l / S l^{d}$ anemic mice. Blood. 53:492-497.

30. Galli, S. J., and Y. Kitamura. 1987. Animal model of human disease. Genetically mast cell-deficient $W / W^{v}$ and $S l / S l^{d}$ mice: their value for the analysis of the roles of mast cells in biological responses in vivo. Am. J. Pathol. 127:191-198.

31. Mekori, Y. A., and S. J. Galli. 1985. Undiminished immunologic tolerance to contact sensitivity in mast cell-deficient mice. $J$. Immunol. 135:879-885.

32. Mekori, Y. A., H. F. Dvorak, and S. J. Galli. 1986. ${ }^{125}$ I-Fibrin deposition in contact sensitivity reactions in the mouse. Sensitivity of the assay for quantitating reactions after active or passive transfer. $J$. Immunol. 136:2018-2025.

33. Wershil, B. K., Y. A. Mekori, T. Murakami, and S. J. Galli. 1987. ${ }^{125} \mathrm{I}$-Fibrin deposition in IgE-dependent immediate hypersensitivity reactions in mouse skin. Demonstration of the role of mast cells using genetically mast cell-deficient mice locally reconstituted with cultured mast cells. J. Immunol. 139:2605-2614.

34. Dvorak, H. F., V. S. Harvey, and J. McDonagh. 1984. Quantitation of fibrinogen influx and fibrin deposition and turnover in line 1 and line 10 guinea pig carcinoma. Cancer Res. 44:3348-3354.

35. Galli, S. J., and I. Hammel. 1984. Unequivocal delayed hypersensitivity in mast cell-deficient and beige mice. Science (Wash. DC). 226:710-713.

36. Dvorak, H. F., M. C. Mihm, Jr., A. M. Dvorak, B. A. Barnes, E. J. Manseau, and S. J. Galli. 1979. Rejection of first set skin allografts in man. The microvasculature is the critical target of the immune response. J. Exp. Med. 150:322-337.

37. Wershil, B. K., T. Murakami, and S. J. Galli. 1988. Mast cell-dependent amplification of an immunologically nonspecific inflammatory response. Mast cells are required for the full expression of cutaneous acute inflammation induced by phorbol 12-myristate 13-acetate. J. Immunol. 140:2356-2360.

38. Martin, T. R., S. J. Galli, I. Katona, and J. M. Drazen. 1989. The role of mast cells in anaphylaxis. Evidence for the importance of mast cells in the pulmonary alterations and death induced by anti-IgE in mice. J. Clin. Invest. 83:1375-1383.

39. Nakano, T., T. Sonoda, C. Hayashi, A. Yamatodani, Y. Kanayama, T. Yamamura, H. Asai, Y. Yonezawa, Y. Kitamura, and S. J. Galli. 1985. Fate of bone marrow-derived cultured mast cells after intracutaneous, intraperitoneal and intravenous transfer into genetically mast cell-deficient $W / W^{v}$ mice. Evidence that cultured mast cells can give rise to both connective tissue-type and mucosal mast cells. $J$. Exp. Med. 162:1025-1043.

40. Mekori, Y. A., J. C. C. Chang, B. K. Wershil, and S. J. Galli. 
1987. Studies of the role of mast cells in contact sensitivity responses: passive transfer of the reaction into mast cell-deficient mice locally reconstituted with cultured mast cells: effect of reserpine on transfer of the reaction with DNP-specific cloned T cells. Cell Immunol. 109:3953.

41. Otsu, K., T. Nakano, Y. Kanakura, H. Asai, H. R. Katz, K. F. Austen, R. L. Stevens, S. J. Galli, and Y. Kitamura. 1987. Phenotypic changes of bone marrow-derived mast cells after intraperitoneal transfer into $W / W^{v}$ mice that are genetically deficient in mast cells. $J$. Exp. Med. 165:615-627.

42. Kanakura, Y., H. Thompson, T. Nakano, T.-I. Yamamura, H. Asai, Y. Kitamura, D. D. Metcalfe, and S. J. Galli. 1988. Multiple bidirectional alterations of phenotype and changes in proliferative potential during the in vitro and in vivo passage of clonal mast cell populations derived from mouse peritoneal mast cells. Blood. 72:877885 .
43. Fewtrell, C. M. S., J. C. Foreman, C. C. Jordan, P. Oehme, H. Renner, and J. M. Stewart. 1982. The effects of substance P on histamine and 5-hydroxytryptamine release in rat. J. Physiol. (Lond.). 330:393-411.

44. Mazurek, N., I. Pecht, V. I. Teichberg, and S. Blumberg. 1981. The role of the $\mathrm{N}$-terminal tetrapeptide in the histamine releasing action of substance P. Neuropharmacology. 20:1025-1027.

45. Stimler-Gerard, N. P. 1987. Neutral endopeptidase-like enzyme controls the contractile activity of substance $P$ in guinea pig lung. J. Clin. Invest. 79:1819-1825.

46. Erdös, E. G., and R. A. Skidgel. 1989. Neutral endopeptidase 24.11 (enkephalinase) and related regulators of peptide hormones. FASEB (Fed. Am. Soc. Exp. Biol.) J. 3:145-151.

47. Goetzl, E. J., T. Chernov, F. Renold, and D. G. Payan. 1985. Neuropeptide regulation of the expression of immediate hypersensitivity. J. Immunol. 135:802s-805s. 